\title{
EXPLORING POMPEII: DISCOVERING HOSPITALITY THROUGH RESEARCH SYNERGY
}

\author{
Kevin D O'Gorman \\ Strathclyde Business School, University of Strathclyde, Glasgow. \\ Ian Baxter and Bernadette Scott \\ Cultural Business Group, Glasgow Caledonian University, Glasgow.
}

\begin{abstract}
Hospitality research continues to broaden through an ever-increasing dialogue and alignment with a greater number of academic disciplines. This paper demonstrates how an enhanced understanding of hospitality can be achieved through synergy between archaeology, the classics and sociology. It focuses on classical Roman life, in particular Pompeii, to illustrate the potential for research synergy and collaboration, to advance the debate on hospitality research and to encourage divergence in research approaches. It demonstrates evidence of commercial hospitality activities through the excavation hotels, bars and taverns, restaurants and fast food sites. The paper also provides an example of the benefits to be gained from multidisciplinary analysis of hospitality and tourism.
\end{abstract}

\section{INTRODUCTION}

With the publication of Hospitality: A social lens Lashley, Lynch and Morrison (2006) make the case that hospitality research is in the process of gaining a more multidisciplinary perspective. They argue that the field of hospitality management maturing both through intellectual advances and by engaging in a broader spectrum of inquiry. This is coupled with the increasingly held belief that more critical perspectives drawing on the breadth of the social sciences can better inform the management of hospitality. Finally there is the desire to challenge the orthodox, conventional wisdom and rhetoric by drawing attention to novel and previously peripheral hospitality associated areas worthy of study, and a wish to engage the mainstream debate of social sciences. 
Current developments within thinking in hospitality have certain parallels with archaeology. Although responding to distinct disciplinary trajectories, classics and archaeology, where triangulated with sociology, provide exciting opportunities for the interdisciplinary understanding of the culture of hospitality provision and consumption and service in different locations and times. It is particularly interesting to consider the approach taken by archaeology to sites, such as Pompeii, as this discipline also has seen changes over time in conceptual frameworks, types of research, and thematic foci for academic investigation from within its own disciplinary perspective. Indeed, consideration of the changing approach of archaeologists and the scholars of history, art history and material culture, who might also be called archaeologists at Pompeii (and elsewhere), shows a close but previously little recognised relationship between distinct disciplines.

\section{DEVELOPMENTS IN ARCHAEOLOGICAL INVESTIGATION}

Classical archaeology developed as a distinct branch of the broader discipline of archaeology, partly as a result of letters published by the German scholar Joachim Winckelmann (Winckelmann 1762) on salvage work at Herculaneum near Pompeii. This branch of the discipline developed through relations with art history and other historical studies of classical Mediterranean culture, benefiting from the existence of written texts to support discoveries of physical evidence and remains (Renfrew and Bahn 1991, Venables 1997). This reflects the changing approach to the study of the past by archaeology and the sub-discipline of classical archaeology over the past 200 years (Trigger 1990). Such disciplinary development, characterised at its most broad level, provides a useful comparator for the development of thought in hospitality, as pre-existing interdisciplinary links can be clearly identified.

Archaeology in its earliest form (the excavation and retrieval of artefacts) was linked to the study of art and culture. This focus, which predominated in 18th and 19th centuries, then developed in the first part of the 20th century towards peopling the physical material evidence. Art and literature could provide a research focus for archaeological investigation focusing on people rather than artefacts. At the same time the development of sociology and geography as disciplines further influenced an 
agenda, which was becoming more interested in how societies had operated and what could be gleaned about such societies from their physical remains. At its most basic, studies might be said to have shifted from asking what the artefacts can say about the people who made them, to how the society was structured and what went on at a location that had produced particular kinds of artefacts.

The latter part of the 20th century has seen huge advances in archaeological method and thought, with particular development of scientific techniques during the 1960s80 s, and development of interpretative techniques from the 1980s to the present day. During this time there has been (and is now seen in archaeological research agendas) the appearance of lifeways with places now being pursued for exploration to discover how people had lived. In some cases individuals from the past can be focused in on, given the right kind of scientific analysis matched against documentary, linguistic and other kinds of research evidence. Non-traditional uses and users of places are being explored, as are alternative lenses for the interpretation of physical evidence (Hodder 2003), to the point of recreating environments virtually for understanding by people with different perspectives (see for example Ellis 2004a, Ellis 2004b, and Johnson 1999).

In essence then there has been a three-stage shift in approach of archaeology to the study of the past: from material culture to people, and more recently, from people to lifeways. The widening of expertise and interpretative lenses used by archaeologists in this latter period reflects that particular discipline's harnessing of techniques and ideas from the humanities, sciences and the social sciences. Past environments are thus now being explored from particular points of view, be they physical (environment and technologies of past societies); spatial (use of space and interrelationships of people and place); or socio-cultural (inter and intra-societal relationships, embodiment, behaviours and cosmologies).

\section{ArChaeology at PompeiI}

The sites of Pompeii and Herculaneum in Italy near modern day Naples are unique; the comparative analysis states in the official World Heritage Site designation 
documentation prepared by UNESCO, "nowhere else is it possible to identify any archaeological site that even remotely stands comparison with these two classical towns" (World Heritage Centre (UNESCO) 1996: 52). Such a statement is based on the circumstances surrounding the almost instantaneous destruction of the city in history by the eruption of Mount Vesuvius in 79AD, and its literal fossilisation as an archaeological site. Archaeology in its early amateur, and latterly professional, form has had the opportunity to undertake systematic excavation and analysis on a huge scale, hindered very little by the usual taphonomic (decay and degration) processes which traditionally affect the preservation of archaeological remains (see for example Renfrew and Bahn 1991 and Venables 1997).

Although the ruins had been known about since the 16th century, the first limited archaeological retrieval of works of art following clearance of the ruins was undertaken in the mid 18th century. The King and Queen of Naples were the patrons of this salvage work, and the Royal collection of items taken from the site was catalogued in 1755. Scientific excavation began at Pompeii in 1850's when Guiseppe Fiorelli (Fiorelli 1854; 1860) excavated full buildings, consolidated walls, re-roofed certain structures and uncovered wall-paintings and other artistic material remains for preservation in-situ. He also went on to develop the technique for creating plaster casts of humans killed by the volcanic eruption, which had been preserved as bodyshaped voids in the overlying ash and volcanic material. Further sustained and largescale excavations were subsequently undertaken in the early part of the 20th century, with the aim of uncovering and preserving specific named houses, and other structures.

The latter part of the 20th century has seen a change in excavation strategy toward uncovering, restoring and research into entire quarters of the town. This type of area excavation has been more systematic in its research aims, uncovering more of the history of the settlement prior to the volcanic eruption, rather than on retrieval or recovery of high-profile spot finds or individual structures. The most recent excavations have seen the research agenda move on again, and these are geared around understanding the social context in uses and purposes of the buildings and structures, and the interrelationship of buildings within an area or by function as reported on by for example: Ellis 2004a, Ellis 2006, and Ellis and Devore 2005. 
Reconstruction of past environments, both virtually using computer technology, and physically using experimental archaeology techniques, are now adding to archaeology's disciplinary development, particularly in providing audiences for new interpretative opportunities and allowing new questions to be asked or ideas to be explored.

\section{COMMERCIAL HoSPITALITY IN CLASSICAL ROME}

Hospitality networks were of critical importance to the Romans. The god Jupiter was thought to watch over the ius hospitia (law of hospitality) in the Roman Empire; the violation of hospitality was a great crime and impiety in Rome. The poet Ovid in Metamorphose highlighted this when he told the story of the gods Jupiter and Mercury who came to earth in human form and travelled around looking for a place to rest. After being turned away a thousand times, the gods came upon the simple thatched cottage of Baucis and Philemon. Baucis and Philemon had little to offer, but generously shared what they had (Ovid, Metamorphoses 8:1026ff). They were about to kill their only goose to feed their guests, when the gods revealed themselves. Jupiter and Mercury took Baucis and Philemon up the mountain to see the valley, in which the homes of all their neighbours, who had turned away the strangers, had been flooded. Their own simple home had been transformed into a temple, of which they then became the priests.

Private hospitality was established between individuals by mutual presents, or by the mediation of a third person, and hallowed by religion. When hospitality was formed between two individuals they would divide between themselves a token called a tessera hospitalis (hospitality token), by which, afterwards, they themselves or their descendants, as the connection was hereditary, might recognise one another (Plautus, Poenulus 5:2:87ff). The tessera bore the image of Jupiter, emphasising Jupiter's divine protection of hospitality; when this kind of hereditary hospitality was established, it could not be dissolved except by a formal declaration and in this case, the tessera hospitalis was broken into pieces. 
Although similar in nature to that of Ancient Greece, private hospitality seems to have been more precisely and legally defined. According to Schmitz (1875) the character of a hospes, i.e., a person connected with a Roman by ties of hospitality, was deemed even more sacred, and to have greater claims upon the host, than that of a person connected by blood or affinity. The connection of hospitality with a foreigner imposed various obligations upon a Roman. Amongst those obligations were: to receive in their house the hospes (traveller); "they enjoyed the hospitality of private citizens whom they treated with courtesy and consideration; and their own houses in Rome were open to those with whom they were accustomed to stay" (Livy, Ab urbe condita 42:1). There were also duties of protection; and, in case of need, to represent a guest as their patron in the courts of justice.

O'Gorman (2006) notes that hospitality in Rome was never exercised in the indiscriminate manner, as it had been in the heroic age of Ancient Greece, and that the custom of observing the laws of hospitality was probably common to all the nations of what was to become modern day Italy. In many cases it was exercised without any formal agreement between the parties, and it was deemed an honourable duty to receive distinguished guests into the house. Public hospitality seems likewise to have existed at a very early period among the nations, "throughout the City the front gates of the houses were thrown open and all sorts of things placed for general use in the open courts, all comers, whether acquaintances or strangers, being brought in to share the hospitality" (Livy, Ab urbe condita.5:13). These kind and generous acts of hospitality lead to long lasting friendships between the host and the guest and it was from these personal bonds that the public ties of hospitality were later to be formed.

\section{ROMANS AND HOSPITALITY PROVISION AND CONSUMPTION}

As archaeologists and historians painstakingly search for authentic material puzzle pieces, to enable the formation of holistic pictures from which to make sense of and indeed amplify the understanding of lost civilisations, the social act of hospitality provision and consumption is much harder to quantify. The impacts which cultural artefacts such as buildings or the discovery of cooking implements have on the formation of historical evidence in a tangible sense provide essential cornerstones on 
the How and the When of the puzzle, they do not however always explain the Why. Faas (1994:1) has suggested that in order to understand the art and sophistication of classical Roman cuisine one has to dig deeper. We do not have the ability to experience actual Roman hospitality events or sample exact food dishes, made in perfect measure in the correct conditions. This frustration is compounded as contemporary Romans do not consume much of the food that their ancestors had enjoyed, although an examination of modern and popular Mediterranean dishes indicates the survival of elements of the old cuisine (e.g. pizza and paella). However modern interpretation of the writings of the times (as in Edwards 1988; Urbán, 1995), together with archaeological findings (for example Kleberg 1957, Ellis 2004a, 2004b) can be used to help create a framework of consumption. In order to attempt an analysis of the intangible Why a structuralist approach is required, which involves the extraction of meanings and the examination of individual signs of hospitality elements. The attached symbolic interactions will enable the articulation of the role of food within the Roman Empire and its importance to lifestyle and consumption paradigms.

Hospitality and the culinary arts were very much at the centre of Roman life. Feasts centred around the gods, some of whom were identified with: hospitality; celebration; consumption, and hunting (providing the commodities to feast). These feasts provided much of the cultural impetus to reinforce the importance of indulgence and consumption of hospitality and events to the Roman way of life (Gowers 1993). Daily meals and routines added leisure values due to the social interactions and hierarchies of the time. Food and eating as part of the Roman hospitality function, was certainly an essential part of their daily life and was rich in semiology, artistic parallels and symbolism.

The Romans are ideal and interesting subjects to facilitate an analysis of patterns of hospitality consumption due to their indulgent reputations and need for ritualistic ceremony with its inherent symbolism. Also, for their basic belief that food and eating is an art form that punctuates everyday life and therefore can provide a rich tapestry of information on life in classical times unlike other social data. "Anyone who would know something worth while about the private and public lives of the 
ancients should be well acquainted with their table... man is what he eats". (Vehling 1977:3).

\section{THE ROMAN FOOD EVENT}

The study of classical Roman food and cookery relies on an Apician viewpoint. Who or what exactly was Apicius is unclear; Hornblower and Spawforth (2003) note that Apicius was the proverbial cognomen for several connoisseurs of food. According to Groag et al (1933) the most famous (and probably the second) was Marcus Gavius Apicius lived in the early Empire (c. 30BC). Much to the disgust of the moralist Seneca (Consolatio ad Helviam, 8f), this Apicius is held to have kept an academy, in the manner of a philosopher. A third Apicius, or even a group of Apicii, lived in the late 4 th or early 5 th century and redacted the surviving Roman cookbook bearing his name.

Pliny the Elder (Naturalis Historia 19:137) and Tacitus (Annales) both note that the famous M. Gavius Apicius moved in the circles of Emperor Tiberius (AD 14 - 37). Pliny considered that Apicius was born to enjoy every extravagant luxury that could be contrived (Naturalis Historia 9:66). This Apicius invented various dishes and sauces in which the pursuit of the refined delicacy was taken to eccentric extremes. According to Athenaeus (Deipnosophistae, 1.5f), having heard of the boasted size and sweetness of the shrimps taken near the Libyan coast, Apicius commandeered a boat and crew, but when he arrived, disappointed by the ones he was offered by the local fishermen who came alongside in their boats, turned round and had his crew return him to his villa without going ashore. All of the subsequent translations of the Apician writings across the centuries concede that they were written to enhance the mysticism of the Roman cook and did not provide recipes that were easy to follow (no exacting measures etc). Vehling (1977:10) has suggested that this is an attempt at self-preservation and that the secret codes required to decipher the text were a way to protecte the cook's earning power and place in society.

Domestic food consumption patterns centred on the provision of a light breakfast (often taken as a snack in the streets as they went about their business), lunch (also a 
snack - consumed at home or most usually in the cool of the bathhouse) and dinner, which was considered most important and almost a reward for the day's toil. Dupont (1994) notes that commodities and quantities eaten varied according to ritual and these were based on social standing, income, age and gender. Slaves were widely and cheaply used (but well-fed) and patronage to early forms of popular catering was the norm for the free citizens. For this large group of Romans their living accommodation typically did not have the basic utilities required to permit safe domestic preparation and consumption. The impacts of these hierarchically driven service needs and requirements on early commercial hospitality provision fuelled development, growth and entrepreneurial activity in the sector (see Garnsey 1998, 1999; Shelton 1988).

Roman celebrity cooks enjoyed notoriety and fashion leaders, such as Petronius (AD 27 - AD 66), provided much to the consumption gossip and trend setting of the day. The infamous Petronius was the arbiter elegantiae (arbiter of good taste) at the court of the Emperor Nero (Thiel 1971); Tacitus (Annales 16:17-20) describes Petronius as hedonistic and witty. Petronius also wrote the Cena Trimalchionis Trimalchio's Dinner (Satyricon 26:6 - 78:8) that describes the typical food, drink and conversation of a Roman feast (see Bagnani 1954). The cook in Rome commanded the title of Artist. The social importance of the feast and the associated religious significance meant that the power of these individuals was encouraged and indulged.

Generally cooking methods relied on the predominant use of sauces and cooking liquors with the heady addition of herbs and spices, such as lovage, cumin and pepper. The Romans often would not tolerate the consumption of any meat, fish or vegetables in their purest forms (Vehling 1977) and indeed revelled in the social expectation that encouraged food to be disguised, either by shape (use of moulds) or the swapping of one food stuff for another (e.g. vegetable puree in the shape of fish), with the direct intent to pass this off as fish to delighted guests. Typical commodities mentioned in the Apicius cookbook (translated by Edwards 1988) include ostrich, goat, dormouse, nettles and eel. Although these were generally expensive, however the slave labour to enable the production was plentiful. Much of the food however was probably inedible or certainly indigestible due to the emphasis placed on creation and art form, “... peas with pieces of gold, lentils with onyx, beans with amber and rice with pearls" (Opilius 
Macrinus, cited in Fass, 1994:28). Lavish food events were the preoccupation of the upper classes (both in public and private), although the lower echelons of Roman society would aspire to attend, and did manage to at times (often as forms of entertainment), and also certainly indulged in their own types of feasting (Blanc and Nercessian 1997).

\section{COMMERCIALISATION OF HOSPITALITY IN THE ROMAN EMPIRE}

The Roman Empire itself was a vast centre of consumption. It imported much of its food from its many colonies under exclusive agreements and expected unusual food gifts for the aristocracy (André 1981). In addition there was market expansion and the wholesale exportation of goods, services and cultural ideas through the colonisation process of the conquered lands. Contemporary western cuisine still has evidence of the culinary practices and commodities of classical Rome (and others), included in the staple meat and vegetation, which was originally introduced to sustain the invading armies (Sirks 1991).

Early forms of commercialisation did much to aid the growth of the Roman hospitality industry. The importance of the work/leisure dichotomy of Roman times was part of their approach to life and undoubtedly emerged as reward and in celebration for their successes in the expansion and growth of the Empire. The result was a historical celebration of indulgence with activities sanctioned it seems by the many gods dedicated to the cause. Roman baths were a daily retreat for most of the population in the intense heat of mid-day. As an early form of leisure based on health motivations, these not only provided a cooling function for civilians, but also provided essential social interactions which would often influence choice of company at the most important meal event of the day: dinner (Fass 1994).

The importance of hospitality was not to be taken lightly and restaurants, bars and brothels were also common leisure respites. The act of cooking itself was said to be a popular pastime due to the lack of literature, however the woman of the house was not expected to cook. Wealthy Roman women were truly 'ladies of leisure' and the slaves took care of domestic chores including meal provision. Roman events ranged 
from the Orgy to the arena, where everyone (regardless of social standing) had a right to attend. Leisure activities took up most of the Roman's time, "they took holy days - so many, in fact, that they spent more days at leisure than we do with our summer breaks and weekends" (Fass 1994:23).

\section{POMPEII: EARLY CENTRE OF CONSUMPTION AND FASHION}

Pompeii is of importance to the examination of hospitality as it was a major centre of eating and entertainment in the Roman world, and hospitality existed in a highly organised fashion. It also provides conclusive case evidence in a concentrated and preserved way, which is ideal for the examination of elements of hospitality, in order to enable the construction of a collective paradigm. The treasure has been uncovered to show how Pompeians catered for themselves domestically and also as consumers of commercial hospitality (Jashemski, 1964). The tangible evidence in an archaeological sense has provided many highly preserved puzzle pieces (location and volume) to illustrate the importance of the hospitality function to the wealthy and cosmopolitan citizens. Indeed, Vehling (1977) has reported that they were enjoying a sporting event in their local amphitheatre when Vesuvius erupted.

Kleberg (1957) defined four principal categories of commercial hospitality establishments in classical Roman: hospitia; stabula; tabernae; and popinae, these terms have become the standard for the archaeological categorisation of classical hospitality businesses:

- Hospitia were establishments that offered rooms for rent, and often food and drink to overnight guests (DeFelice 2001). Packer (1978) asserts that hospitia were expressly fabricated for business purposes, although a number of them represent secondary uses of existing private homes in Pompeii.

- Stabula had an open courtyard surrounded by a kitchen, a latrine, and bedrooms with stables at the rear. Businesses within city gates were smaller than those in the countryside, due to pressure of space (Packer 1978). Casson (1974) observed that in Rome stabulae were probably the most common type of overnight accommodation. They were hospitia with facilities to shelter 
animals; often found just outside the city, close to the city gates, the "classical equivalent of modern motels" (Packer 1978:44)

- Taberna, in the first century A.D., referred to either a shop or a tavern, however in many publications, the term taberna refers to almost any kind of shop, so there is a good deal of confusion when compiling a list of such establishments from secondary sources (DeFelice 2001). Tabernae, in their first century AD sense, served a variety of simple foods and drink. They usually contained a simple L-shaped marble counter, about six to eight feet long, with a simmering pot of water and shelves of other food on the back wall of a tiny room, often just large enough for the proprietor and several assistants (Kleberg 1957; Casson 1974; Packer 1978).

- Popinae were also establishments limited to serving food and drink. Some may have offered sit down meals; this term was often used to describe public eating-houses.

In summary then: tabernae and popinae had no facilities for overnight guests whilst hospitia and stabula usually did. Hospitiae were normally larger than stabulae and a stabula would have had accommodation to keep animals as well as guests. According to DeFelice (2001) hospitiae, stabulae, tabernae, and popinae were not always standalone businesses; often a hospitia or stabula would have a taberna or popina connected with or adjacent to them. These commercial hospitality businesses existed for travellers, merchants, and sailors who came to trade and sell, or those who were stopping overnight along the way to other destinations. From the discussion about the reciprocal nature of private hospitality it is already clear that not all travellers required such services DeFelice (2001) asserts that hospitiae and stabulae along major roads and at city gates gained a reputation for attracting lower classes who were too poor or socially insignificant to have developed a network of personal hospitality; in other literature of the time hospitiae also had a reputation for bedbugs, discomfort, violence and danger. Although originally at lower levels, O'Gorman (2005) identifies that the subsequent provision of higher levels of hospitality establishment and service was a direct consequence of the ability of the higher classes to afford to travel to lands where there are not known, but it enables them to be in environments which are commensurate with their wealth and status, without the need to establish a household there. 
Hospitae, tabernae, stabulae, popinae, and lumpnar (brothels) have been found together with detailed kitchens and bakeries some with fossilised loaves of bread. The Pompeii insights provide proof of the advanced technology used on a daily basis by the people within organised and structured social spaces, which are not too far removed from contemporary examples. Inscriptions have been found in Pompeii that highlight both the mercantile nature of hospitality and level of service provision available. This is also symbolic evidence with regard to lifestyle and consumption statements indicative with branding and a sophisticated level of marketing. In addition the strategic geographical concentration of hospitality services within the town suggest the synergised ease of hospitality provision and consumption. Packer (1978) illustrates the importance of food and the social act of eating and hospitality indulgence to the inhabitants and tourists of the time. This provides an essential insight into wider social phenomena within the town; Vehling (1977:7) confirms this by stating "those who would know something about the classical table cannot do without Pompeii".

The lifestyle, culture and consumption conclusions derived from the evidence provided from the examination of hospitality writings and tangible archaeological finds (with the attached importance of the proximity of associated facilities) indicate that the provision and consumption of hospitality in the Roman world was indeed regarded as a mark of civilisation. Commercial motives are evident in both the organisation of facilities and advertising efforts, menus of the day etc. Early entertainments and events were highly organised activities, central to the leisure of the day and given prime geographical location to emphasise this importance. The skills involved in organising these often mass spectacles is not to be overlooked and Pompeii in its role as a centre of leisure would have attracted and required the best hospitality employees, which the Empire could offer, in order to maintain and improve its central function. It was ultimately a place for mercantile and leisure activities with a developed and sophisticated hospitality service across recognisable sectors. In this centre of consumption consumers demonstrated lifestyle perspectives by virtue of their engagements in the many aspects of hospitality, including symbolic hospitality, food and eating rituals. The analysis of these elements can aid the 
determination of provision and consumption patterns across a wider area and provide highly qualitative information on lifestyle patterns and cultural practices.

\section{THE VALUE OF INTERDISCIPLINARY SYNERGY}

This paper has illustrated interdisciplinary triangulation of archaeology, classics and sociology focusing on hospitality, this approach appears to be charting a similar threestage development in thinking to that of archaeology. Archaeological techniques and format of evidence retrieval from Pompeii has changed over time; the early excavations at Pompeii saw treasures and works of art being retrieved for display in a Royal Palace. The development of archaeological thought and technique provided a more scientific basis related to this, with the pursuit of understanding of the material culture of past societies, as well as the physical remains of earlier civilisations or societies. Essentially, scientific interest set out to catalogue remains and to create typologies of material by which locations and amorphous societies could be understood. The comparative literary and sociological material (such as was available for Pompeii and Roman society) provides a basic contextualisation for this physical evidence.

Researchers in archaeology who are drawn to the more theoretical interpretations of embodiment currently espoused in the social sciences, appear to be itching to make such interdisciplinary links. This can be seen for example in the range of papers edited by Ralph (2005) for a recent special edition of the journal, Archaeological Review from Cambridge, as well as work of Ellis (2004b, 2006). Within the edition of ARC, consideration was given by authors to feasting; food and drink (and other hedonistic pursuits); social notions of quality; and authenticity and identity creation through foods, amongst other topics.

Stimulation is required for more opportunities for academic research questions related to modern day issues of hospitality provision and consumption and also leisure management. An example of these links that have already been made between the current studies of commercial hospitality in Pompeii is Ashworth and Tunbridge's modelling of the tourist-historic city (Ashworth 1990) written from a tourism 
geography perspective. Archaeology has made some initial investigations into the role of hospitality provision and consumption through the literary and academic assessments of the role of food and drink in Roman society (Briers 1990; Renfrew 2004) and the potential to develop this further has been demonstrated in this paper. The social science studies approach as an umbrella for such interdisciplinary work has great potential for interesting collaborations and understandings. Such research reinforces the need for continued theoretical underpinning by the science of the cognate disciplines. 


\section{REFERENCES}

Modern Sources

André, J. (1981) L'Alimentation et la Cuisine à Rome. Les Belles Lettres, Paris Ashworth, G.J. (1990) The Tourist-Historic City. Belhaven, London.

Bagnani, G. (1954) Arbiter of Elegance: a study of the life and works of C. Petronius. Oxford University Press, London.

Blanc, N. and Nercessian, A. (1997) La Cuisine Romaine Antique. Glénat, Faton.

Briers, A. (1990) Eat, drink and be merry: the foods available and enjoyed by the classical Greeks and Romans, water and wine and the traditions which grew up around them, how people enjoyed themselves and the changing fashions of entertainment and manners in Greek and Roman times. Ashmolean Museum, Oxford:

Casson, L. (1974) Travel in the Ancient World. Allen and Unwin, London.

DeFelice, J.F. (2001) Roman Hospitality: The Professional Women of Pompeii. Shangri-La Publications, Warren Center.

Dupont, F. (1994) Vie Quotidienne du Citoyen Romain sous la République. Hachette Littérature, Paris.

Edwards, J. (1988) The Roman Cookery of Apicius: Translated and adapted for the modern kitchen. Century, London.

Ellis, S.J.R. (2004a) The distribution of bars at Pompeii: archaeological, spatial and viewshed analyses. Journal of Roman Archaeology, Vol. 17, pp. 371-384.

Ellis, S.J.R. (2004b) The Pompeian Bar: archaeology and the role of food and drink outlets in an classical community. Food \& History, Vol. 2, pp. 41-58.

Ellis, S.J.R. (2006) Social patterns in the Pompeian Urban Fabric: Discovering bars, restaurants, and houses in a new excavation project at Pompeii. Seminar Presentation at John Cabot University, Rome.

Ellis, S.J.R. \& Devore, G. (2005) Pompeii Archaeological Research Project: Porta Stabia [online], available from: http://www.stanford.edu/group/pompeii/ [accessed 01/08/06]

Fass, P (1994), Around the Roman Table. Palgrave, New York.

Fiorelli, G. (1854) Monvmenta Epigraphica Pompeiana ad Fidem Archtyporvm Expresa. Caiet. Nobile, Neapoli.

Fiorelli, G. (1860) Pompeianarum Antiquitatum Historia. Caiet. Nobile, Neapoli.

Garnsey, P. (1998) Cities, Peasants, and Food in Classical Antiquity: Essays in social and economic history. Cambridge University Press, Cambridge.

Garnsey, P. (1999) Food and Society in Classical Antiquity. Cambridge University Press, Cambridge.

Gowers, E. (1993) The Loaded Table: Representations of Food in Roman Literature. Clarendon Press, Oxford.

Groag, E., Stein, A. and Petersen, L. (1933) Prosopographia Imperii Romani. W. de Gruyter, Berolini.

Hodder, I. (2003) Reading the Past: Current approaches to interpretation in archaeology. Cambridge: Cambridge University Press.

Hornblower, S. and Spawforth, A. (eds) (2003) The Oxford Classical Dictionary, Oxford University Press, Oxford.

Jashemski, W.F. (1964) A Pompeian Copa. Classical Journal Vol. 59, pp. 337-349 
Johnson, M. (1999) Archaeological Theory: An introduction. Oxford. Blackwell Publishers.

Kleberg, T. (1957) Hôtels, Restaurants et Cabarets dans L'antiquité Romaine: Études Historiques et Philologiques. Almqvist \& Wiksell, Uppsala.

Lashley, C., Lynch, P. and Morrison, A. (eds) (2006) Advances in Tourism Research, Hospitality: A Social Lens. Elsevier, Oxford.

O'Gorman, K.D. (2005) Modern Hospitality: Lessons from the past, Journal of Hospitality and Tourism Management, Vol. 12, No 2. pp 131 -141.

O’Gorman, K.D. (2006) Dimensions of Hospitality: Exploring Ancient and Classical Origins. In C. Lashley, P. Lynch and A. Morrison (eds) Advances in Tourism Research, Hospitality: A Social Lens. Elsevier, Oxford.

Packer, J.E. (1978) Inns at Pompeii: A Short Survey. Cronache Pompeiane. Rivista dell'Associazione Internazionale 'Amici di Pompei'. Vol. 4, pp. 5-53.

Ralph, S. (2005) (Volume Editor) Archaeological Review from Cambridge. Issues of Food and Drink - An interdisciplinary approach, Vol. 20, No. 2.

Renfrew, C. and Bahn, P. (1991) Archaeology: Theories, Method \& Practice. London: Thames \& Hudson.

Renfrew, J.M. (2004) Roman Cookery: Recipes \& history. English Heritage, Swindon.

Schmitz, L. (1875) Hospitium. In: Smith, W. (ed) A Dictionary of Greek and Roman Antiquities, J. Murray, London.

Shelton, J.A. (1988) As the Romans Did: A source book in Roman social history. Oxford University Press, Oxford.

Sirks, B. (1991) Food for Rome: the legal structure of the transportation and processing of supplies for the imperial distributions in Rome and Constantinople. J.C. Gieben, Amsterdam.

Thiel, H.V. (1971) Petron: Überlieferung und Rekonstruktion. Brill, Lugduni Batavorum.

Trigger, B.G. (1990) A History of Archaeological Thought. Cambridge University Press, Cambridge.

Urbán, A. (1995) Concordantia Apiciana: A concordance to Apicius' De re coquinaria and Excerpta a vinidario with an analysis of the lexicon. Olms-Weidmann, Hildesheim.Venables, R. (1997) Pompeii. Pendeen, Penzance.

Vehling, J D. (1977) Apicius: Cookery and Dining in Imperial Rome. Dover Publications, New York.

Winckelmann, J. J. (1762) Sendschreiben von den Herculanischen Entdeckungen. Verlegts George Conrad Walther, Dreszden.

World Heritage Centre (UNESCO) (1996) World Heritage List Extract: Pompei and Ercolano (Italy) No 829. UNESCO World Heritage Centre, Paris.

\section{CLASSICAL SOURCES}

Note references to Greek and Latin texts used in the paper, employ the standard English-language citation system. The Loeb Classical Library has been used for the works cited in this paper. 
Livy, $A b$ urbe condita

Ovid, Metamorphose

Petronius, Satyricon

Plautus, Poenulus et

Cistellaria.

Pliny the Elder, Naturalis

Historia

Seneca, Consolatio ad

Helviam

Tacitus Annales
History of Rome. Loeb Classical Library, Assorted Volumes. Heinemann 1916 -1949.

Metamorphoses. Loeb Classical Library, Volume 42 - 43. Heinemann, 1916.

Satyricon. Loeb Classical Library, Volume 15. Heinemann, 1913.

Poenulus et Cistellaria in The little Carthaginian, Pseudolus, The Rope. Loeb Classical Library, Volume 163. Heinemann 1921

Natural History. Loeb Classical Library, Assorted Volumes. Heinemann 1938 - 1965

Moral essays. Loeb Classical Library, Volume 214. Heinemann 1935.

Annals. Loeb Classical Library, Volume 312. Heinemann 1947 